\title{
UN CUSCO QUE SE VA. IN MEMORIAM RICARDO VALDERRAMA FERNÁNDEZ (1945-2020)
}

\author{
Luis Miguel Glave*
}

No pecamos de exageración al decir que las muestras de dolor y de cariño que se dieron luego del fallecimiento de Ricardo Valderrama fueron abrumadoramente enormes. Desde luego que incidió en ello el que Ricardo al momento de su deceso estuviera ejerciendo el cargo de alcalde de su ciudad, el Cusco. También que la causa de su muerte fuera la pandemia que asola la humanidad hace meses y no sabemos hasta cuándo. Podríamos suponer entonces de que se trataba de ceremonias protocolares o un colectivo sentimiento de consternación por la época. Nada más alejado de la realidad. El dolor y el cariño eran tan evidentes que convirtieron el triste suceso en una celebración de identidad y un canto a la amistad y la admiración por un ser humano. Al cúmulo de homenajes regionales se sumó otro número muy grande de condolidas manifestaciones del mundo de la academia. Podría pensarse, equivocadamente también, que fueran formulismos propios de un espacio que no escapa al acartonamiento y la figuración. Lo cierto es que también en el campo de los profesionales de la antropología y las ciencias sociales, se expresó el reconocimiento al ser humano, indesligable de su obra.

Nuestro querido Valderrama murió en acto de servicio social. Le tocó que al final de su vida, habiendo elegido incursionar en las instituciones públicas para lograr medidas que apoyaran a la cultura local y a la mejor vida de las gentes de una ciudad con la que se identificaba, esto lo llevara a exponerse ante el cruento virus del que trataba de proteger a todos. Pienso que Ricardo decidió combinar sus labores como docente con la participación en el municipio porque ya la edad no le permitía seguir subiendo montañas, trajinando caminos de piedra, viviendo en asentamientos comunales de grandes alturas, interactuando como uno más entre los comuneros. Valderrama era en eso irrepetible, un incansable etnógrafo.

Difícilmente se hallará otro investigador igual de ágil y avispado para llegar allí donde pareciera que el mundo "moderno" se acaba. Huancavelica, Cotabambas, Colca, Poques y tantos otros lugares, los más aislados, donde la vida de los seres humanos recuerda cómo la historia desigual del "desarrollo" de Perú los dejaba excluidos, olvidados, oprimidos. Allí llegó Ricardo, con bigote a la mexicana, caminar pausado, mirada inquisitiva y brillante, voz ronca con la que pronunciaba un quechua sublime. A su manera empírica, con la guía de su corazón y su intuición, sabía que allí encontraría un mundo vivo, ancestral, que tenía enseñanzas para el Perú urbano y moderno y guardaba celoso retazos de la historia nacional que está por escribirse. En eso también Valderrama era infalible. Sabía dónde estaba ese Perú profundo, sabía cómo ir a buscarlo, ir a desentrañarlo. Se hacía parte de las colectividades que quería estudiar, premunido de su palabra, de su simpatía, de su habilidad para desempeñar roles como maestro, como sanitario o asesor letrado.

Buscaba voces perdidas en el tiempo, rituales, costumbres, mitos y relatos. Era incontenible para ello y cuando encontraba el paraguas de alguna institución que lo patrocinara, o sin patrocinio y solo empujado por su pasión, le faltaba tiempo para empacar y salir al campo. No era la suya una agenda formada en libros, seminarios o congresos. Sí escuchó a sus maestros pero más a los seres humanos, los runas, a los que comprendía no solo por su habilidad lingüística sino también por su ser social: un hombre nacido en un pueblo de la personalidad que tiene San Gerónimo, que vivió el Cusco de medio siglo, la sociedad de indios, mestizos y señores que retrató José María Arguedas. Estudió en las aulas antonianas de su universidad, cuando los maestros eran venerables ensayistas, prosistas, cusqueñistas. Se formó en la estela del nacimiento del Cusco rojo que retrató Julio Gutiérrez y cuando se manifestó luego en sonoras movilizaciones políticas que se mostraron indomables abriendo el camino para la reforma agraria que cambiaría el país. Todavía lo recuerdo entusiasta a finales de

* El Colegio de América, Universidad Pablo de Olavide. Sevilla, España. Correo electrónico: 1mglave@ hotmail.com 
los setentas en una noche del día jubilar del Cusco cuando, acelerando el paso a la voz de ¡Sutep Sutep Sutep! -el sindicato de los trabajadores de la educación- hacía una reivindicación política en medio del jolgorio de la fiesta por excelencia de la ciudad. Ricardo se había metido varias veces en los escalones de maestros que desfilaban en la fiesta, como muchos ciudadanos, de manera que el paso del magisterio parecía interminable, como los aplausos de la gente en la plaza, en días en que los maestros de escuela cusqueños libraban una larguísima y sin duda heroica lucha por sus derechos, que desafiaba al poder central.

Su habilidad etnográfica se manifestó potente en 1974 cuando participó, incluso como actor, en el famoso corto documental de Julio Figueroa El cargador. Esa es una pieza fundamental de la historia del cine peruano. Ya le nacía la idea de hacer una historia de vida con el testimonio de Gregorio Condori Mamani, respecto de quien giró el documental. Hizo un largo y profundo trabajo de registro del testimonio, viviendo casi con el testigo. El encuentro de esos dos hombres del Cusco fue un feliz suceso para la historia de nuestra cultura peruana. Ambos vivaces lenguaraces, hablaron y hablaron, buceando en la memoria andina. La Autobiografía de Gregorio, que vio la luz gracias al apoyo del fundador y director del Centro Bartolomé de Las Casas, Guido Delran Cousi, será un libro inmortal que revisitaremos una y otra vez y siempre tendrá algo nuevo que decirnos. Algo nuevo pero salido de un testimonio de siglos, por boca de un humilde cargador, un huaccha, que unió en su vida andariega, lo urbano y lo rural, en el proceso de cambio de una sociedad que se iba, pero dejando una huella, una herencia, inmortal. Esas son las obras maestras. Retales del vestido de la historia, historia ellas mismas.

Valderrama no se quedó quieto nunca, ni en sus salidas al campo ni en su empeño por escuchar y formarse en el campo académico. No solo su paso por el Centro Las Casas fue un impulso a su carrera, estudió también en la Universidad Católica de Lima, salió al extranjero convocado por especialistas que nunca han ocultado su admiración por su trabajo, gracias a lo que obtuvo una beca de la John Simon Guggenheim Foundation. Siempre fue generoso, tanto en su esfuerzo, que era para él un placer, de salir al campo, como en su acopio de libros y papeles que guardaba y compartía en su biblioteca de San Gerónimo. Su labor fue compartir, querer difundir sus hallazgos. Sus alumnos en la universidad, como se ha visto, lo querían y apreciaban. Y no se equivocaban al hacerlo, bien pueden tenerlo como ejemplo.

Unió su vida a su pareja de siempre, Carmen Escalante. Formaron un tándem estupendo. Todo lo que hemos dicho de él no se entiende sin ella. Hicieron el grueso de sus trabajos juntos, firmaron ambos sus publicaciones. Se complementaron de una manera muy productiva, dando uno al otro algo de los saberes que eran necesarios para emprender sus investigaciones. Viajaron y vivieron en el campo, Carmen se enorgullece de recordar que ella podía poner a raya a los abigeos y que su fuerza se amparaba en su compañero. Yo la recuerdo cuando estando embarazada de su primer hijo, bajábamos desde Maras hacia Urubamba bajo la lluvia, cuando divisamos un camión que iba por la polvorienta carretera y corrimos para subirnos en él: ¡yo más preocupado que ella por su estado! acostumbrada a esos y más rudos trajines del trabajo de campo en esos años. Viajaron al extranjero, compartieron estrados y mesas de trabajo. Siempre juntos. Es entrañable la escena en que Ricardo Valderrama recibe el mando de la ciudad de manos de Carmen Escalante, con un beso. Lejos estaba de imaginar que tendría que despedirlo entre sollozos poco tiempo después.

Las contribuciones de los esposos Valderrama Escalante han sido numerosas, no solo la obra testimonial de Gregorio Condori y de su esposa Asunta Quispe, también relatos de ritos y ceremonias, etnografías locales ricas en testimonios de primera mano, manejados con la sapiencia de quienes eran parte integrante de esa sociedad que estudiaban. Incluso incursionaron en la historia, muy al principio, en una publicación de Pablo Macera en el Seminario de Historia Rural Andina, sobre un alzamiento indígena en Aquira y Quiñota. Ya en su madurez, rescatando una valiosa colección de documentos familiares que hablan de la construcción de esos linajes locales que se reivindicaban como descendientes de los señores del reino. Pero como repito, nada de ello es entendible sin la naturaleza de los seres humanos que registraron esa historia y esa cultura. Como reza el título de uno de sus libros, con otros testimonios de vida recogidos por ambos en Cotabambas: Nosotros los humanos. Ñucanchik runakuna.

Descansa en paz querido compañero y que tu sacrificio no sea en vano. 